\title{
HUBUNGAN MINAT BELAJAR DAN MOTIVASI BELAJAR TERHADAP PRESTASI AKADEMIK MAHASISWA JURUSAN BIMBINGAN \& KONSELING UNIVERSITAS PGRI ADI BUANA SURABAYA
}

\author{
Cindy Asli Pravesti \\ Dosen Bimbingan dan Konseling FKIP-Universitas PGRI Adi Buana Surabaya \\ cindyaslibks2a12439@gmail.com
}

\begin{abstract}
Abstrak
Prestasi akademik hasil capaian mahasiswa dalam proses belajar di kampus yang dinyatakan dalam wujud nilai yang tertera dalam indeks prestasi melalui kehadiran, tugas, ujian tengah semester, dan ujian akhir semester. Kesuksesan mahasiswa dalam meraih prestasi akademik yang sangat memuaskan merupakan wujud dari ketercapaian tujuan pendidikan. Tentunya hal ini terkait dengan faktor-faktor yang mempengaruhi prestasi akademik, adapun faktor tersebut terbagi atas faktor internal dan faktor eksternal. Namun, dalam penelitian ini lebih melihat pada faktor internal, diantaranya minat belajar dan motivasi belajar. Minat belajar adalah kecenderungan terhadap pemusatan perhatian dalam kegiatan belajar yang diungkap melalui perasaan senang, ketertarikan, adanya perhatian, dan adanya keterlibatan dalam belajar yang diukur dengan skala minat belajar. Motivasi belajar adalah dorongan ingin tahu, dorongan ingin sukses, dan dorongan ingin bekerja sama dalam melakukan aktivitas belajar guna mencapai tujuan belajar, diukur dengan skala motivasi belajar. Tujuan dari penelitian ini ialah memperoleh model yang tepat untuk menggambarkan hubungan sebab akibat antara minat dan motivasi dengan prestasi akademik dan memperoleh gambaran empirik mengenai hubungan sebab akibat minat dan motivasi belajar sebagai variabel bebas terhadap prestasi akademik mahasiswa sebagai variabel terikat.
\end{abstract}

Guna menunjang tujuan tersebut, maka Rancangan penelitian yang digunakan ialah penelitian korelasional. Populasi penelitian terdiri atas seluruh mahasiswa bimbingan dan konseling Universitas PGRI Adi Buana Surabaya TA 2015/2016 dengan pengambilan sampel menggunakan propotional stratified random sampling. Sampel seluruhnya berjumlah 104 orang. Instrumen yang digunakan berupa skala yang mengukur minat belajar dan motivasi belajar, sedangkan untuk mengetahui prestasi akademik mahasiswa menggunakan dokumentasi yang berupa indeks prestasi kumulatif. Analisis data dalam penelitian ini menggunakan analisis regresi.

Hasil penelitian ini diketahui bahwa hasil analisis regresi diketahui bahwa model teoretis hubungan sebab akibat minat, motivasi terhadap prestasi akademik pada mahasiswa menghasilkan jalur-jalur yang signifikan antarvariabel. 
Interpretasi dilakukan untuk membentuk suatu teori baru berupa gambaran jalur dalam pembentukan hubungan sebab akibat minat belajar, motivasi belajar terhadap prestasi akademik pada mahasiswa. Adapun dari data empiris didapatkan bahwa pada mahasiswa minat dan motivasi belajar berpengaruh secara simultan dan positif terhadap prestasi akademik. Minat belajar berpengaruh secara langsung terhadap motivasi belajar dan minat belajar berpengaruh secara langsung terhadap prestasi akademik. Jalur tersebut didukung oleh koefisien total kontribusi minat belajar terhadap motivasi belajar sebesar 0,786. Sedangkan jalur minat belajar terhadap prestasi akademik sebesar 0,166. Pada variabel motivasi belajar juga memiliki pengaruh secara langsung terhadap prestasi akademik. Adapun koefisien jalur pada motivasi belajar terhadap prestasi sebesar 0,166.

Kata Kunci: Minat Belajar, Motivasi Belajar, Prestasi Akademik.

\section{Pendahuluan}

Skinner (dalam Hitipeuw, 2009) menyatakan bahwa tindakantindakan pebelajar (behavior or response) dalam hal ini yang dimaksudkan ialah individu dalam hal ini mahasiswa lebih dikontrol oleh konsekuensi yang menyertai tingkah laku tersebut daripada peristiwa yang men-dahuluinya. Misalnya konsekuensi berupa nilai yang diperoleh mahasiswa setelah mengerjalan tugas atau ujian. Bila nilai mahasiswa bagus maka mahasiswa tersebut akan mempertahankan cara belajar dalam menyelesaikan ujian, tugas atau pekerjaan rumah (PR) dan bahkan akan mencoba meningkatkan. Sebaliknya bila nilainya rendah, mahasiswa akan mengubah cara belajarnya di kemudian hari. Hal inilah yang dinamakan belajar, mahasiswa mengalami perubahan tingkah laku yang semula lalai menjadi lebih disiplin dalam belajar.
Adanya perubahan tersebut terlihat dalam prestasi akademik yang dihasilkan oleh mahasiswa berdasarkan evaluasi yang diberikan oleh dosen. Syah (2006) mengemukakan bahwa prestasi akademik mahasiswa adalah prestasi akademik dalam perkuliahan yang relatif bersifat permanen setelah melalui proses belajar dalam jangka waktu tertentu. Untuk mencapai prestasi akademik tersebut, Syah (2006) menyatakan bahwa ada beberapa faktor yang mempengaruhi yaitu faktor internal dan faktor eksternal. Faktor internal terdiri atas aspek fisik dan psikologis (bakat, sikap, kebiasaan, minat, motivasi dan intelegensi); Faktor eksternal terdiri atas lingkungan sosial dan lingkungan non sosial. Lunandi (1993) menyatakan bahwa sumber terkaya untuk bahan belajar adalah dalam diri sendiri. Ini menyiratkan bahwa salah satu faktor penting dalam pencapaian prestasi akademik ialah faktor internal. Ungkapan yang sama juga disampaikan Widayatun (1999) yakni 
faktor domain yang menentukan prestasi seseorang ialah intelegensi. Hal tersebut juga menyiratkan bahwa faktor internal menjadi penting dalam keberhasilan mencapai prestasi akademik.

Maka, penting untuk mengetahui faktor internal seperti minat dan motivasi mahasiswa yang berkontribusi dalam pencapain prestasi akademik. Goldberg (1994) juga menyatakan bahwa seorang mahasiswa dengan motivasi intrinsik dalam belajar akan memiliki self-perceptions tinggi terhadap kompetensi akademik daripada faktor ekstrinsik yang dirasa kurang terhadap kompetensi akademik. Maka terindikasi bahwa faktor internal yakni minat, dan motivasi memiliki kontribusi lebih besar serta nampak bersifat stabil juga tahan lama (Tobias, 1994) daripada faktor eksternal yang terdiri dari lingkungan sosial dan lingkungan non sosial.

Pada tingkat Perguruan Tinggi (PT), penilaian prestasi akademik dinyatakan dalam bentuk indeks prestasi semester. Indeks prestasi merupakan penghitungan IP dengan semua mata kuliah yang telah ditempuh untuk tiap semester tertentu. Norma nilai berkisar antara 4 (A, terbaik) sampai 0 (E, gagal). Adapun tahap perkembangan pada mahasiswa telah memasuki fase remaja akhir. Menurut Henderson \& Dweck, 1990 (dalam Santrock, 2003) remaja akhir adalah masa yang penting dalam hal prestasi, yang dimaksudkan yakni prestasi akademik, sehingga mulai dituntut untuk melihat kesuksesan atau kegagalan dalam belajar pada masa kini untuk meramalkan keberhasilan di kehidupan mereka nanti sebagai orang dewasa. Hal tersebut senada dengan ungkapan Hanurawan (2008) bahwa remaja akhir memiliki kemampuan berpikir dengan cara mempertimbangkan kemungkinan pada masa lalu, sekarang, dan saat ini. Lebih lanjut diungkapkan juga bahwa dalam diri remaja akhir terjadi peningkatan dalam minat-minat berpikir.

Melihat begitu besar konsekuensi pengaruh dari prestasi akademik tentunya akan lebih baik jika dilakukan proses membantu pada hal tersebut. Diperlukan pengetahuan mengenai faktor-faktor yang memberi sumbangan yang signifikan pada prestasi akademik mahasiswa. Adapun sumbangan terbesar yang mempengaruhi prestasi akademik mahasiswa yakni faktor internal atau faktor yang datang dari diri sendiri. Sebuah penelitian yang mencari tahu tentang hubungan minat dan motivasi berpengaruh pada prestasi akademik (Crede \& Kuncel, 2008). Prestasi akademik merupakan sebuah gambaran konkret keberhasilan proses belajar mengajar yang berlangsung di kampus, prestasi Akademik juga dapat menjadi tolok ukur dari tingkat pemahaman mahasiswa tentang materi tertentu yang telah diberikan, setelah mengalami proses belajar pada jangka waktu tertentu hasilnya dinyatakan dalam bentuk nilai. 
Sebagai upaya untuk mengidentifikasi hubungan setiap aspek terhadap prestasi akademik mahasiswa maka, perlu dilakukan suatu penelitian yang relevan dan akurat mengenai hal tersebut, sehingga dapat diketahui faktor mana yang pada akhirnya membantu intervensi terbentuknya prestasi akademik pada mahasiswa. Maka fokus dari penelitian ini, ialah memperoleh model prestasi akademik mahasiswa sebagai hubungan sebab akibat minat belajar dan motivasi belajar terhadap prestasi akademik mahasiswa jurusan Bimbingan Konseling UNIPA Surabaya.

\section{Prestasi Akademik}

Shih (2005) menyebutkan bahwa tujuan prestasi akademik didefinisikan sebagai tujuan keterlibatan tugas yang menentukan pendekatan seseorang untuk tipe kegiatan yang guna mencapai prestasi (Ames, 1992; Dweck \& Leggett, 1988; Maehr, 1989). Pernyataan tersebut dapat diartikan bahwa keterlibatan tugas, yakni evaluasi semester dalam kegiatan belajar menjadi tujuan dari prestasi akademik. Syah (2011) mendukung pernyataan tersebut yang menyatakan bahwa prestasi akademik merupakan hasil interaksi dari sebagian faktor yang mempengaruhi proses belajar secara keseluruhan yang meliputi segenap ranah psikologis yang berubah sebagai akibat pengalaman dan proses belajar mahasiswa.
Prestasi akademik pada dasarnya adalah hasil akhir yang diharapkan dapat dicapai setelah seseorang belajar. Hasil belajar atau bentuk perubahan tingkah laku yang diharapkan itu merupakan suatu target atau tujuan pembelajaran yang meliputi 3 (tiga) aspek yaitu: 1) tahu, mengetahui (knowing); 2) terampil melaksanakan atau mengerjakan yang ia ketahui itu (doing); dan 3) melaksanakan yang ia ketahui itu secara rutin dan konsekuen (being). Pernyataan tersebut didukung oleh Benjamin S. Bloom yang mengklasifikasikan hasil belajar menjadi tiga ranah, yakni 1) ranah kognitif (cognitive domain); 2) ranah afektif (affective domain); dan 3) ranah psikomotor (psychomotor domain).

Dari beberapa pernyataan diatas, dapat disimpulkan bahwa prestasi akademik merupakan hasil capaian maha-siswa dalam proses belajar di kampus yang dinyatakan dalam wujud nilai yang tertera dalam indeks prestasi melalui kehadiran, tugas, ujian tengah semester, dan ujian akhir semester.

Prestasi akademik di kampus sangat dipengaruhi oleh kemampuan umum kita yang diukur oleh IQ, IQ yang tinggi dapat meramalkan kesuksesan prestasi akademik. Namun demikian pada beberapa kasus, IQ yang tinggi ternyata tidak menjamin kesuksesan seseorang dalam belajar dan hidup bermasyarakat.

IQ bukanlah satu-satunya faktor penentu kesuksesan prestasi 
akademik seseorang. Ada faktor-faktor lain yang turut andil mempengaruhi perkembangan prestasi akademik. Sehubungan dengan hal ini faktorfaktor yang mempengaruhi prestasi akademik diklasifikasikan menjadi dua bagian, yaitu faktor intern dan faktor ekstern.

Pernyataan ini didukung oleh Crede \& Kuncel (2008) yang menyatakan bahwa dua hal yang paling sering digunakan sebagai prediktor prestasi akademik: prestasi akademik sebelumnya dan skor pada tes penerimaan. Konstruksi dari kedua hal tersebut menunjukkan bahwa minat dan motivasi belajar memainkan peran penting dan sentral dalam menentukan kinerja akademik.

\section{Minat Belajar}

Definisi secara sederhana juga dikemukakan Syah (2011) yang mengartikan minat kecenderungan dan kegairahan yang tinggi atau keinginan yang besar terhadap sesuatu. Pernyataan ini mengidentifikasikan bahwa orang yang berminat akan ada rasa tertarik. Tertarik dalam hal tersebut merupakan wujud dari rasa senang pada sesuatu. Hal tersebut didukung oleh Slameto (2010:57), yang menyatakan minat sebagai kecenderungan yang tetap untuk memperhatikan terus-menerus pada suatu hal atau aktivitas.

Hilgard (dalam Slameto, 2010:57) memberi rumusan tentang minat, yakni kecenderungan untuk memperhatikan dan menikmati beberapa kegiatan atau konten. Ini diartikan bahwa minat merupakan kecenderungan yang tetap untuk memperhatikan dan mengenang beberapa kegiatan. Minat pada dasarnya memiliki penerimaan akan suatu hubungan antara diri sendiri dengan sesuatu di luar diri. Semakin kuat atau besar hubungan tersebut, semakin besar minat.

Minat belajar yang dipahami dan dipakai selama ini dapat mempengaruhi kualitas pencapaian prestasi akademik. Sehingga diartikan anak yang berminat terhadap sesuatu kegiatan belajar, akan berusaha sekuat tenaga untuk mencapai tujuan yang diinginkan. Berdasarkan penjelasan di atas maka minat belajar diartikan sebagai kecenderungan terhadap pemusatan perhatian dalam kegiatan belajar yang diungkap melalui perasaan senang, adanya ketertarikan, dan adanya perhatian serta keterlibatan.

Minat mempunyai pengaruh yang besar dalam belajar karena bila bahan perkuliahan yang dipelajari tidak sesuai dengan minat mahasiswa maka mahasiswa tersebut tidak akan belajar dengan sebaik-baiknya, sebab tidak ada daya tarik baginya. Sedangkan bila bahan per-kuliahan itu menarik minat mahasiswa, maka ia akan mudah dipelajari dan di-simpan karena adanya minat sehingga menambah kegiatan belajar. Salah satu yang mempengaruhi minat, yakni motivasi, yang dalam belajar lebih besar sebagai motivating force yaitu sebagai 
ke-kuatan yang mendorong mahasiswa untuk belajar. Mahasiswa yang berminat kepada perkuliahan akan tampak terdorong terus untuk tekun belajar, berbeda dengan mahasiswa yang sikapnya hanya menerima perkuliahan.

Sehingga dari faktor-faktor tersebut diatas dapat disimpulkan bahwa minat individu dari Ainley dkk. (2002) yang menganggap minat sebagai kecenderungan individu untuk mengikuti terhadap rangsangan tertentu, peristiwa, dan objek tertentu. Rangsangan tertentu, peristiwa, dan objek tertentu yang dimaksudkan dalam penelitian ini ialah minat akan belajar. Ini sejalan dengan pemikiran minat personal dari Krapp dkk. (1992) yang menyatakan bahwa minat yang permanen dan stabil yang mengarah pada minat akan belajar, yakni suatu bentuk rasa senang ataupun tidak senang, tertarik tidak tertarik terhadap mata perkuliahan. Sehingga yang disampaikan Safari (2003) untuk mengetahui berapa besar minat belajar mahasiswa, dapat diukur melalui perasaan senang, adanya ketertarikan, dan adanya perhatian serta keterlibatan.

\section{Motivasi Belajar}

Motivasi menurut Gleitman (1986); Reber (1988) dalam Syah (2011) diartikan sebagai pemasok daya (energizer) untuk bertingkah laku searah. Tingkah laku searah merupakan tujuan yang ingin dicapai oleh mahasiswa, yakni prestasi akademik yang baik. Hal tersebut didukung oleh Schunk (2008) yang menyatakan bahwa motivasi merupakan proses mendorong dan mempertahankan tujuan dengan mengarahkan perilaku. Schunk (2008) juga menyatakan maha-siswa termotivasi mencapai prestasi akademis dengan terlibat dalam perilaku belajar. Lebih lanjut Hanurawan (2007) menyampaikan bahwa motivasi adalah konstruk psikologi yang menjadi dorongan untuk terjadinya suatu perilaku atau tindakan. Dalam konteks pendidikan motivasi dapat dilihat sebagai dorongan yang menggerakkan aktivitas belajar dalam diri mahasiswa.

Dari penjelasan tersebut di atas maka dapat disimpulkan bahwa motivasi belajar adalah dorongan yang berhubungan dengan prestasi akademik mahasiswa, yakni dorongan ingin tahu, dorongan ingin sukses, dan dorongan ingin bekerja sama dalam melakukan aktivitas belajar guna mencapai tujuan belajar.

Senada dengan ungkapan tersebut Bruner, 1966 (dalam Brookhart, 2010) menyatakan bahwa semua motivasi intrinsik melibatkan satu atau lebih dari kategori yang berdasar pada energi alami yang mendukung secara spontan dalam pembelajaran. Adapun kategorinya: rasa ingin tahu, dorongan untuk mencapai kompetensi atau kesuksesan, serta kebutuhan untuk bekerjasama dengan orang lain dalam mencapai tujuan belajar. 
Berdasarkan faktor-faktor di atas maka dapat disimpulkan bahwa motivasi dapat diukur melalui: a) dorongan ingin tahu yang meliputi senang mencari dan memecahkan masalah belajar, tekun menghadapi tugas, ulet dalam belajar; b) dorongan ingin sukses, meliputi keyakinan dalam belajar, memiliki orientasi masa depan dalam belajar, tekun dalam belajar; c) dorongan ingin bekerjasama, meliputi keterlibatan aktif dalam belajar, menghendaki perhatian dalam belajar, keberhasilan mencapai tujuan belajar.

\section{Hubungan Minat Belajar dan Motivasi Belajar terhadap Prestasi Akademik}

Adanya perubahan tersebut terlihat dalam prestasi akademik yang dihasilkan oleh mahasiswa berdasarkan evaluasi yang diberikan oleh dosen. Syah (2006) mengemukakan bahwa prestasi akademik mahasiswa adalah prestasi akademik dalam perkuliahan yang relatif bersifat permanen setelah melalui proses belajar dalam jangka waktu tertentu. Untuk mencapai prestasi akademik tersebut, Syah (2006) menyatakan bahwa ada beberapa faktor yang mempengaruhi yaitu faktor internal dan faktor eksternal. Faktor internal terdiri atas aspek fisik dan psikologis (bakat, sikap, kebiasaan, minat, motivasi dan intelegensi); Faktor eksternal terdiri atas lingkungan sosial dan lingkungan non sosial. Lunandi menyatakan bahwa sumber terkaya untuk bahan belajar adalah dalam diri sendiri. Ini menyiratkan bahwa salah satu faktor penting dalam pencapaian prestasi akademik ialah faktor internal. Ungkapan yang sama juga disampaikan Widayatun (1999) yakni faktor domain yang menentukan prestasi seseorang ialah intelegensi. Hal tersebut juga menyiratkan bahwa faktor internal menjadi penting dalam keberhasilan mencapai prestasi akademik.

Maka, penting untuk mengetahui faktor internal seperti minat dan motivasi mahasiswa yang berkontribusi dalam pencapain prestasi akademik. Goldberg (1994) juga menyatakan bahwa seorang mahasiswa dengan motivasi intrinsik dalam belajar akan memiliki self-perceptions tinggi terhadap kompetensi akademik daripada faktor ekstrinsik yang dirasa kurang terhadap kompetensi akademik. Maka terindikasi bahwa faktor internal yakni minat, dan motivasi memiliki kontribusi lebih besar serta nampak bersifat stabil juga tahan lama (Tobias, 1994) daripada faktor eksternal yang terdiri dari lingkungan sosial dan lingkungan non sosial.

Pada tingkat Perguruan Tinggi (PT), penilaian prestasi akademik dinyata-kan dalam bentuk indeks prestasi semester. Indeks prestasi merupakan peng-hitungan IP dengan semua mata kuliah yang telah ditempuh untuk tiap semester tertentu. Norma nilai berkisar antara 4 (A, terbaik) sampai 0 (E, gagal). Adapun tahap perkembangan pada mahasiswa telah memasuki fase remaja akhir. 
Menurut Henderson \& Dweck, 1990 (dalam Santrock, 2003) remaja akhir adalah masa yang penting dalam hal prestasi, yang dimaksudkan yakni prestasi akademik, sehingga mulai dituntut untuk melihat kesuksesan atau kegagalan dalam belajar pada masa kini untuk meramalkan keberhasilan di kehidupan mereka nanti sebagai orang dewasa. Hal tersebut senada dengan ungkapan Hanurawan (2008) bahwa remaja akhir memiliki kemampuan berpikir dengan cara mempertimbangkan kemungkinan pada masa lalu, sekarang, dan saat ini. Lebih lanjut diungkapkan juga bahwa dalam diri remaja akhir terjadi peningkatan dalam minat-minat berpikir.

Melihat begitu besar konsekuensi pengaruh dari prestasi akademik tentunya akan lebih baik jika dilakukan proses membantu pada hal tersebut. Diperlukan pengetahuan mengenai faktor-faktor yang memberi sumbangan yang signifikan pada prestasi akademik mahasiswa. Adapun sumbangan terbesar yang mempengaruhi prestasi akademik mahasiswa yakni faktor internal atau faktor yang datang dari diri sendiri. Sebuah penelitian yang mencari tahu tentang hubungan minat dan motivasi berpengaruh pada prestasi akademik (Crede \& Kuncel, 2008). Prestasi akademik merupakan sebuah gambaran konkret keberhasilan proses belajar mengajar yang berlangsung di kampus, prestasi Akademik juga dapat menjadi tolok ukur dari tingkat pemahaman mahasiswa tentang materi tertentu yang telah diberikan, setelah mengalami proses belajar pada jangka waktu tertentu hasilnya dinyatakan dalam bentuk nilai.

Terdapat beberapa faktor yang mempengaruhi prestasi akademik menurut Slameto (2010) yang digolongkan menjadi dua golongan, yakni faktor internal maupun faktor eksternal. Faktor internal ialah faktor yang ada dalam diri individu, berupa motivasi, minat, bakat, kebiasaan belajar maupun kecerdasan mahasiswa itu sendiri. Faktor eksternal ialah faktor yang ada di luar diri individu, seperti sarana dan prasarana kampus, kurikulum, dosen, lingkungan dan materi perkuliahan. Dari faktor yang menunjang prestasi akademik tersebut, secara keseluruhan dapat diketahui bahwa semua faktor tersebut saling melengkapi dan menunjang prestasi akademik.

Faktor internal tersebut khususnya motivasi, dan minat belajar karena faktor internal itu merupakan modal yang dimiliki diri mahasiswa sehingga lebih mempunyai dorongan terhadap pening-katan prestasi akademik. Ini didukung oleh penelitian Schiefele (1991) bahwa mengindikasikan pentingnya minat terhadap motivasi belajar guna mencapai tujuan belajar. Lebih lanjut, mengenai pentingnya kontribusi faktor internal pada prestasi akademik juga disampaikan oleh Tobias (1994) bahwa telah terindikasi faktor internal yakni minat dan motivasi memiliki 
kontribusi lebih besar serta nampak bersifat stabil juga tahan lama daripada faktor eksternal yang terdiri dari lingkungan sosial dan lingkungan non sosial.

Penelitian Subramaniam (2009) menyebutkan bahwa minat serta motivasi merupakan dua hal penting yang dapat mempengaruhi keterlibatan mahasiswa dan prestasi dalam belajar. Crede \& Kuncel (2008) mengungkapkan dalam studinya bahwa faktor internal memprediksi prestasi akademik menjadi lebih tinggi daripada faktor eksternal yang mengobservasi hubungan antara ling-kungan pribadi dan prestasi akademik memiliki tipe yang rendah. Hasil penelitian Lestari (2009) menunjukkan pengaruh faktor internal yang terdiri atas, minat, kebiasaan dan motivasi sebesar 59,6\% terhadap prestasi akademik.

Maka prestasi akademik merupakan hal yang penting dalam mengetahui tingkat pemahaman mahasiswa terhadap mata kuliah. Dalam penelitian ini khususnya, prestasi akademik yang baik menjadi tujuan dari semua mahasiswa, yang memiliki banyak faktor dalam mencapainya. Diantaranya faktor internal tersebut.

\section{Metode Penelitian}

Penelitian mengenai minat dan motivasi belajar, yang dicari hubungannya dengan prestasi akademik pada mahasiswa jurusan Bimbingan Konseling UNIPA Surabaya ini memakai pendekatan pe- nelitian kuantitatif untuk menguji hipotesis yang telah disusun. Adapun desain penelitian kuantitatif yang digunakan adalah desain korelasional yang bertujuan untuk memprediksi nilai-nilai dan model pengaruh hubungan antar variabel. Desain ini tidak berusaha untuk mengontrol atau memanipulasi variabel, melainkan meng-hubungkan antara dua atau lebih variabel (Cresswell, 2012).

Dalam penelitian ini, variabel yang diteliti adalah dua variabel bebas, yaitu minat belajar dan motivasi belajar, sedangkan prestasi akademik sebagai variabel terikat yang akan diprediksi oleh kedua variabel bebas tersebut. Tujuan penelitian untuk memperoleh pola hu-bungan variabel minat belajar dan variabel motivasi belajar dengan variabel prestasi akademik pada mahasiswa mahasiswa jurusan Bimbingan Konseling UNIPA Surabaya yang mungkin dapat dibentuk dari ketiga variabel yang ada. Secara skematis rancangan penelitian dapat dilihat dalam gambar sebagai berikut:

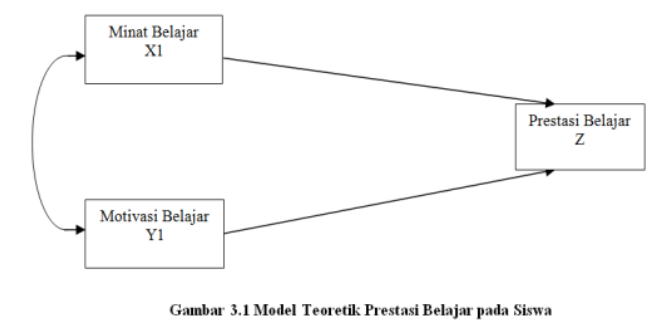

Sampel penelitian adalah bagian dari populasi yang mewakili keseluruhan dari populasi tersebut. Menurut Arikunto (2002:112) jika subjeknya lebih besar (lebih dari 100) 
dapat diambil antara $10-15 \%$ atau 20 $25 \%$. Adapun sampel penelitian ini mengambil taraf $25 \%$ dari total populasi 414 mahasiswa ialah 103,5 dibulatkan menjadi 104 mahasiswa jurusan Bimbingan Konseling UNIPA Surabaya yang menjadi bagian dari populasi penelitian. Metode pengambilan sampel (teknik sampling) yang dipergunakan adalah propotional stratified random sampling sehingga penelitian dilakukan kepada setiap mahasiswa dalam satu kelompok kelas. Pemilihan sampel adalah dengan mengambil seluruh mahasiswa yang terhimpun dalam satu kelompok kelas dalam setiap angkatan.

Penelitian ini menggunakan dua instrumen skala. Kedua skala tersebut yakni (a) skala minat belajar dan (b) skala motivasi belajar. Selain menggunakan dua skala, penelitian ini juga menggunakan dokumentasi. Dokumentasi yang diguna-kan ialah dokumentasi prestasi akademik mahasiswa untuk memperolah data belajar mahasiswa, berupa indeks prestasi mahasiswa pada jurusan Bimbingan Konseling UNIPA Surabaya.

Untuk menghitung validitas
skala minat belajar dan motivasi
belajar dilakukan $\begin{array}{r}\text { dengan } \\ \text { menggunakan bantuan program IBM }\end{array}$
Statistic SPSS 20. Dengan
menggunakan fungsi analisis faktor
eksploratori dengan tujuan untuk
memilih butir valid dan mereduksi
butir tidak valid dengan kriteria

loading $\geq 0,5$ terhadap aspek (atau aspek terhadap konstruk) yang dibangun menurut Hair, dkk, 1998 (dalam Atmoko, 2012). Pada penelitian ini analisis faktor eksploratori digunakan untuk mengidentifikasi faktor/dimensi, sub-variabel dan itemitem untuk mengukur konstruk minat belajar dan motivasi belajar yang telah dirumuskan berdasarkan kajian teori.

$$
\text { Reliabilitas instrumen }
$$

mengguna-kan cara penghitungan reliabilitas internal, yakni dengan penghitungan yang dilakukan berdasarkan data dari instrumen tersebut. Uji reliabilitas menggunakan rumus Alpha Cronbach melalui program IBM Statistic SPSS 20 dengan pertimbangan rumus yang cukup luwes dalam arti formula ini dapat diterapkan pada alat ukur yang memberikan skornya non dikotomi dan dapat dibelah secara seimbang (Azwar, 2008:75).

Terdapat acuan dalam menentukan koefisien reliabilitas yang dihasilkan sebuah instrumen tersebut telah reliabel atau belum. Koefisien reliabilitas ditafsirkan dengan kriteria yang diungkapkan oleh Anastasi dan Urbina (2003) bahwa instrumen dinyatakan reliabel jika nilai koefisien reliabilitas di atas 0,80 yang dirincikan seperti berikut; 0,00-0,79 = tidak reliabel; 0,80-0,84 = cukup reliabel; $0,85-0,89=$ reliabel tinggi; $0,90-1,00=$ reliabel sangat tinggi. 
Untuk menguji hipotesis yang telah diajukan, digunakan alat uji model statistik yaitu menggunakan analisis regresi linier berganda (multiple regression), dengan model matematik sebagai berikut:

$\mathrm{Y}=\mathrm{a}+\mathrm{b} 1 \mathrm{X} 1+\mathrm{b} 2 \mathrm{X} 2$

Keterangan:

$$
\begin{aligned}
& \mathrm{Y}=\text { Prestasi Akademik } \\
& \mathrm{X} 2=\text { Motivasi Belajar } \\
& \mathrm{X} 1=\text { Minat Belajar } \\
& \mathrm{b} 1=\text { Koefisien Regresi } \\
& \mathrm{a} \quad=\text { Konstanta } \\
& \mathrm{b} 2 \quad=\text { Koefisien Regresi }
\end{aligned}
$$

\section{Hasil dan Pembahasan}

Responden penelitian ini berjumlah 104 mahasiswa yang diperoleh dengan memperhatikan taraf $25 \%$ dari populasi, maka ukuran responden atau sampel yang dianjurkan ialah 103,5 dibulatkan menjadi 104 mahasiswa jurusan bimbingan dan konseling. Adapun sejumlah data tersebut diperoleh dari mahasiswa angkatan 2012, 2013, 2014, dan 2015.

Diketahui bahwa rata-rata skor minat belajar sebesar 96,98 dengan standar deviasi sebesar 12,48 dari 104 mahasiswa bimbingan dan konseling UNIPA surabaya. Diketahui bahwa skor tertinggi minat belajar yang diperoleh mahasiswa sebesar 123 sedangkan nilai terendah yang diperoleh mahasiswa dalam skala minat belajar sebesar 62. Sedangkan, skor sampel dibagi menjadi tiga kategori yaitu tinggi, sedang, dan rendah dengan memakai patokan mean dan standar deviasi untuk kemudian dicari persentase dari masing-masing kategori. Terdapat 19,23\% (20 orang) mahasiswa memiliki tingkat minat belajar yang masuk dalam kategori rendah, sebanyak $55,77 \%$ (58 orang) mahasiswa memiliki tingkat minat belajar yang sedang, dan sebanyak 25\% (26 orang) memiliki tingkat minat belajar yang tinggi. Dapat dikatakan bahwa sebagian besar mahasiswa bimbingan dan konseling memiliki tingkat minat belajar yang sedang.

Rata-rata skor motivasi belajar sebesar 87,59 dengan standar deviasi sebesar 10,98 dari 104 mahasiswa bimbingan dan konseling UNIPA Surabaya, serta diketahui bahwa skor tertinggi motivasi belajar yang diperoleh mahasiswa sebesar 113 sedangkan nilai terendah yang diperoleh mahasiswa dalam skala motivasi belajar sebesar 51 . Sedangkan, skor sampel dibagi menjadi tiga kategori yaitu tinggi, sedang, dan rendah dengan memakai patokan mean dan standar deviasi untuk kemudian dicari persentase dari masing-masing kategori. Terdapat $9,61 \%$ (10 orang) mahasiswa memiliki tingkat motivasi belajar yang masuk dalam kategori rendah, sebanyak $59,62 \%$ (62 orang) mahasiswa 
memiliki tingkat motivasi belajar yang sedang, dan sebanyak 30,77\% (32 orang) memiliki tingkat motivasi belajar yang tinggi. Dapat dikatakan bahwa sebagian besar maha-siswa bimbingan dan konseling memiliki tingkat motivasi belajar yang sedang.

Mahasiswa bimbingan dan konseling UNIPA surabaya memiliki prestasi akademik dalam kategori sangat memuas-kan sebanyak $60,58 \%$ (104 orang), dan sebanyak 39,42\% (41 orang) dari mahasiswa masuk dalam kategori dengan pujian. Sehingga dapat dikatakan bahwa prestasi akademik mahasiswa bimbingan dan kosneling UNIPA surabaya termasuk dalam kategori sangat memuaskan.

Hasil uji normalitas dengan Kol-mogorov Smirnov Test menunjukkan bahwa sebaran data dari setiap variabel dalam penelitian adalah normal. Hal tersebut dibuktikan dari sigifikansi tiap nilai Kolmogorov Smirnov Test dari tiap variable adalah $>0,05$. Sehingga disimpulkan bahwa variabel minat belajar dengan nilai sebesar $0,632(p=0,820)$, motivasi belajar dengan nilai $0,890(\mathrm{p}=0,406)$, prestasi akademik dengan nilai 1,215 $(\mathrm{p}=0,104)$ adalah terdistribusi mengikuti kurva normal.

Uji asumsi multikolineritas yang dilakukan pada variabel bebas menun-jukkan bahwa pada model regresi tidak terdapat hubungan (korelasi) antarvariabel bebas. Korelasi antar variabel bebas memiliki koefisien yang $<0,5$ sehingga dapat dikatakan bahwa korelasi antar variabel bebas tersebut adalah lemah. Demikian pula dengan Variance Inflation Factor dari tiap variabel lebih kecil dari 10 maka tidak terjadi multikolinieritas atau non multikolinieritas.

Uji asumsi heteroskedastisitas dilakukan terhadap data penelitian dengan berpatokan pada pola tertentu pada grafik scatterplot analisis regresi dasar peng-ambilan keputusan adalah jika tidak terdapat pola jelas sehingga titik-titik juga menyebar di atas dan di bawah angka 0 pada sumbu $\mathrm{Y}$, maka data tersebut tidak terjadi heteroskedastisitas. Pada data penelitian ini ditemukan bahwa grafik sebaran data tampak titik-titik menyebar di atas dan di bawah sumbu $\mathrm{Y}$, tidak terjadi pola tertentu sehingga dapat disimpulkan bahwa tidak terjadi heteroskedastisitas.

Setelah diketahui bahwa data memenuhi syarat untuk dianalisis, maka selanjutnya dapat dilakukan uji hipotesis dengan uji analisis regresi. Berdasarkan hipotesis umum; minat belajar, motivasi belajar, dan berkontribusi dengan prestasi akademik sebesar 0,037 atau 3,7\% dan $\mathrm{p}=0,031$ (tabel 4.10). Ini berarti bahwa model hubungan sebab akibat minat belajar, motivasi belajar dengan prestasi akademik telah dibuktikan secara empiris. Sehingga hipotesis khusus dari hubugan sebab akibat minat, motivasi belajar dengan prestasi 
akademik dapat dijelaskan sebagai berikut.

a. minat belajar secara langsung berpengaruh positif terhadap motivasi belajar

b. minat belajar secara langsung berpengaruh positif terhadap prestasi akademik

c. motivasi belajar secara langsung ber-pengaruh positif terhadap prestasi akademik.

Dari hasil uji validitas model, diketahui bahwa model teoretis hubungan sebab akibat minat, motivasi terhadap prestasi akademik pada mahasiswa menghasilkan jalur-jalur yang signifikan antarvariabel. Interpretasi dilakukan untuk membentuk suatu teori baru berupa gam-baran jalur dalam pembentukan hubungan sebab akibat minat belajar, motivasi belajar terhadap prestasi akademik pada mahasiswa. Adapun dari data empiris didapatkan bahwa pada mahasiswa-siswi SMA minat dan motivasi belajar berpengaruh secara simultan dan positif terhadap prestasi akademik.

Minat belajar berpengaruh secara langsung terhadap motivasi belajar dan minat belajar berpengaruh secara langsung terhadap prestasi akademik. Jalur tersebut didukung oleh koefisien total kontribusi minat belajar terhadap motivasi belajar sebesar 0,786. Sedangkan jalur minat belajar terhadap prestasi akademik sebesar 0,166. Pada variabel motivasi belajar juga memiliki pengaruh secara langsung terhadap prestasi akademik. Adapun koefisien jalur pada motivasi belajar terhadap prestasi sebesar 0,166.

\section{Kesimpulan}

Pendidikan merupakan suatu hal yang sangat penting dan sangat perlu diperhatikan, karena jika pendidikan berjalan dengan baik maka kehidupan juga akan berjalan dengan baik. Pendidikan sendiri memiliki tiga jenis, yakni; pen-didikan formal yang dilaksanakan di sekolah, pendidikan informal dapat dilaksanakan di lingkungan keluarga, dan pendidikan non formal dapat dilaksanakan di masyarakat.

Proses pendidikan di sekolah atau pendidikan formal tentunya tidak lepas dari personil-personil sekolah. Salah satu personil sekolah yang berperan penting dalam pendidikan ialah konselor sekolah yang berada pada kelembagaan bimbingan dan konseling, keberadaan bimbingan dan konseling dalam pendidikan diatur dalam undang-undang No.20 tahun 2003 tentang sistem pendidikan nasional yang ditempatkan sebagai salah satu layanan pendidikan yang harus diperoleh peserta didik, saat ini bimbingan dan konseling telah menjadi salah satu komponen lembaga pendidikan sekolah.

Bimbingan dan konseling di sekolah memiliki 3 komponen, yaitu 
bim-bingan pribadi-sosial, bimbingan belajar, dan bimbingan karir (Shertzer \& Stone, 1981). Pada penelitian ini dapat dijadikan acuan dalam bimbingan belajar. Bim-bingan belajar merupakan proses bantuan mahasiswa untuk mengembang-kan diri yang berkaitan dengan cara belajar yang baik, materi belajar, berbagai aspek tujuan belajar, dan kegiatan belajar lainnya. Layanan bimbingan belajar merupakan layanan guna membantu mahasiswa mengatasi hambatan belajar, sehingga tujuan pendidikan dapat tercapai dengan baik.

Tujuan bimbingan belajar berkaitan dengan prestasi akademik atau prestasi akademik yakni (a) konselor dapat merencanakan layanan informasi berkaitan dengan prestasi akademik, diantaranya bagaimana menetapkan tujuan belajar, bagaimana cara mencapai tujuan yang telah ditetapkan, bagaimana cara menumbuhkan dorongan untuk mendapat nilai atau hasil prestasi akademik yang sangat memuaskan, serta mengatur cara belajar, (b) konselor dapat bekerjasama dengan personil sekolah lainnya atau orang tua untuk membantu dalam belajarnya, (c) konselor dapat memberikan layanan bimbingan belajar kepada mahasiswa baik secara individu maupun kelompok.

Adapun bimbingan belajar yang dapat diberikan dalam penelitian ini berkaitan dengan teori belajar Skinner, belajar merupakan proses perubahan tingkah laku yang terjadi di dalam satu situasi. Situasi belajar ini ditandai secara kompleks, karena dalam proses tersebut mahasiswa tidak hanya sekedar menerima dan menyerap informasi yang disampaikan oleh guru, tetapi mahasiswa dapat melibatkan diri dalam kegiatan pembelajaran dan tindakan pedagogis yang harus dilakukan, sehingga mendapatkan hasil belajar yang lebih baik dan sempurna.

Dari proses atau kegiatan belajar tersebut mahasiswa dapat menghasilkan suatu perubahan yang bertahap dalam dirinya, baik dalam bidang pengetahuan, keterampilan dan sikap. Skinner (dalam Hitipeuw, 2009) menyatakan bahwa tin-dakan-tindakan pebelajar (behavior or response) lebih dikontrol oleh konsekuensi yang menyertai tingkah laku tersebut daripada peristiwa yang mendahuluinya. Misalnya konsekuensi berupa nilai yang diperoleh mahasiswa setelah mengerjalan tugas atau PR atau ulangan. Bila nilai mahasiswa bagus maka mahasiswa ter-sebut akan mempertahankan cara belajar dalam menyelesaikan ujian, tugas atau PR dan bahkan akan mencoba meningkatkan. Sebaliknya bila nilainya rendah, maha-siswa akan merubah cara belajarnya di ke-mudian hari.

\section{Pada Operant Conditioning} juga dianggap berperan dalam pendidikan. Operant Conditioning Skinner menakan-kan bahwa perilaku 
seseorang terbentuk oleh dampak dari efek yang ditimbulkan-nya. Jika efek tersebut berdampak pada penguatan pengaruh stimulus dan respon-nya, maka perilaku tersebut akan cenderung diulang (Slavin, 2008). Contoh, se-orang mahasiswa merasa nilainya kurang memuaskan, dia merasa bahwa belajar merupakan suatu hal yang sesuai untuk memperbaiki nilainya, maka belajar akan menjadi pilihan perilaku ketika dia mendapatkan nilai yang memuaskan.

Dari paparan tersebut di atas maka dapat ditarik kesimpulan bahwa mahasiswa yang memiliki minat belajar dan motivasi belajar yang tinggi, maka mahasiswa tersebut akan memiliki prestasi akademik yang tinggi pula. Jika prestasi akademik yang bagus menjadi kon-sekuensi yang menyenangkan maka mahasiswa akan cenderung terlibat pada perilaku tersebut, yakni mahasiswa cenderung lebih meningkatkan minat belajar dan motivasi belajar sehingga dia akan memiliki prestasi akademik yang bagus.

Untuk itu, bagi konselor untuk lebih menekankan pada aspek minat belajar dan prestasi akademik guna lebih meningkatkan prestasi akademik maha-siswa. Diharapkan hasil dari penelitian ini dapat menambah wacana konselor terkait prestasi akademik mahasiswa. Pada ke-mudian hari konselor dapat segera mem-berikan layanan yang sesuai terkait pres-tasi akademik, yang didasarkan dari hasil penelitian ini bahwa minat belajar dan motivasi belajar menjadi topik utama dalam layanan bimbingan belajar.

\section{Daftar Pustaka}

Ainley, M., Suzanne H. \& Dagmar B. 2002. Interest, Learning, and the Psychological Processes That Mediate Their Relationship. Journal of Educational Psychology, 94(3): 545-561.

Arikunto, S. 2002. Metodologi Penelitian. Jakarta: Rineka Cipta.

Azwar, S. 2009. Penyusunan Skala Psikologi. Yogyakarta: Pustaka Pelajar.

Crede, M., \& Kuncel, N. R. 2008. Study Habits, Skills, and Attitudes - The Third Pillar Supporting Collegiate Academic Performance. Association for Psychological Science, 3(6): 425-453.

Creswell, J. W. 2012. Educational Research : Planning, Conducting, and Evaluating Quantitative and Qualitative Research $4^{\text {th }}$ Edition. Boston: Pearson Education, Inc.

Goldberg, M. D. 1994. A Developmental Investigation of Intrinsic Motivation: Correlates, Causes, and Consequences in High Ability Students (Doctoral Dissertation, 
University of Virginia, 1994).

Dissertation Abstracts

International, 55-04B, 1688.

Hanurawan, F. 2008. Aplikasi Psikologi dalam Masalah Kegagalan Akademis Siswa. Jurnal Kajian Teori dan Praktik Kependidikan, Tahun 35, Nomor 1, Januari 2008.

Hanurawan, F. 2008. Psikologi Pendidikan. Malang: Universitas Negeri Malang.

Hitipeuw, I. 2009. Belajar \& Pembelajaran. Malang: Fakultas Ilmu Pendidikan Universitas Negeri Malang.

Krapp, A., Hidi, S., \& Renninger, A. 1992. Interest, learning and development. In K. A. Renninger, S. Hidi, \& A. Krapp (Eds.), The role of interest in learning and development (pp. 3-25). Hillsdale, NJ: Erlbaum.

Lestari, M. P. A. 2010. Pengaruh Motivasi, Minat, dan Kebiasaan Belajar Siswa terhadap Prestasi akademik Mahasiswa pada Mata Perkuliahan Akuntansi di SMAN Sekota Cirebon. Abstrak. Bandung: Universitas Pendidikan Indonesia.

Lunandi, A. G. 1993. Pendidikan Orang Dewasa. Jakarta: PT. Gramedia Pustaka Utama.

Safari. 2003. Evaluasi Pembelajaran. Departemen Pendidikan Nasional Direktorat Jenderal Pendidikan Dasar dan Menegah.
Santrock, J. W. 2003. Adolescence Perkembangan Remaja. Jakarta: Erlangga.

Schiefele, U. 1991. Interest, Learning, and Motivation. Educational Psychologist, Lawrence Erlbaum Associate, Inc, 26(3\&4): 299-323.

Schunk, D. H., 2012. Learning Theories: An Educational Perspective (Teori - Teori Pembelajaran: Perspektif Pendidikan). Yogyakarta: Pustaka Pelajar.

Shih, S. S. 2005. Role of Achievement Goals in Children's Learning in Taiwan. The Journal of Education Research, ProQuest Professional Education May/Jun 2005, 98(5): 310-319.

Slameto. 2010. Belajar dan FaktorFaktor yang Mempengaruhinya. Jakarta: Rineka Cipta.

Subramaniam, P. R. 2009. Motivational Effects of Interest on Student Engagement and Learning in Physical Education: A Review. International Journal Physical Education, 46.

Syah, M. 2006. Psikologi Belajar. Jakarta: Raja Grafindo Persada.

Syah, M. 2011. Psikologi Belajar. Jakarta: Raja Grafindo Persada.

Tobias, S. 1994. Interest, Prior Knowledge, and Learning. Review of Educational 
Research, ProQuest

Professional Education, Spring 1994, 64(1): 37-54.

Widayatun, T. R. 1999. Ilmu Perilaku.

Jakarta: CV. Sagung Seto. 
